\title{
Representing 'otherness' in African popular media: Chinese Characters in Ethiopian
} Video-Films

\section{Abstract}

This article focuses on the recent phenomenon of Ethiopian films that prominently feature Chinese characters as a point in departure to readdress debates on the role media plays in the construction and representation of "otherness". The commercially driven digital film industry in Ethiopia has emerged as a by-product of recent social and economic changes in the country, with local productions proving hugely popular within Ethiopia and in the Ethiopian diaspora. These films crucially claim their success on their ability to represent and articulate the desires, anxieties, fantasies and uncertainties of lived Ethiopian experiences. Building on recent scholarship committed to understanding the growing influences of China in Africa, we explore Ethiopian representations of China in these films and their significance in terms of their broader social and cultural impacts. As the success of these films relies on representing a stereotypical Chinese "Other", and in reference to China's ever growing presence in African countries, we pose broader questions relating to the place of ethnicity, race and national identity in popular cultural productions emerging from the continent.

\section{Keywords}

Ethiopian cinema, Chinese people in Ethiopia, representation of otherness, popular culture in Ethiopia, autochthony and ethnicity, Ethiopia-China relations. 
Debates on media representation of "otherness" have occupied a central position in media studies, cultural studies and postcolonial studies debates over the past thirty years. The work of scholars such as Edward Said (1978) and Stuart Hall (1997), coupled with those of, among others, Michel Foucault (1980), Cornelius Castoriadis (1987) and Charles Taylor (2004), have been adopted and reinterpreted by media scholars to reveal the tight connection between power dynamics, social imaginaries, and mediated constructions of difference and otherness. Media today are powerful agents in the construction of collective ideas and perceptions of reality; they work at different levels, shaping our imagination in subtle ways, "producing 'truth effects' and legitimising certain discursive regimes, while rendering others illegitimate, deviant and "false"" (Orgad 2012: 28). Within this context, by playing a sort of "boundary work" (Silverstone 2007: 19, quoted in Orgad 2012: 30), media representations of otherness are in many ways central to processes of collective identity formation. Studying them can thus reveal important aspects of how societies respond to the questions that globalisation processes posit to their existence as imagined "homogeneous" collectivities.

Most of the existing research on these issues are based on a North-South perspective that privileges the analysis of Western representations of "its" others (Africa, the "Orient", and the "New World" - see for instance Said 1978; Mudimbe 1988; Mignolo 2005; see also Hallam and Street 2013; Loshitzky 2010) or, more rarely, the gaze of the "Other" toward the West (see for instance Kaur 2002; Okoye 2010). Works focusing on images and imageries that nonWestern societies have of other non-Western societies are much rarer, and studies about the way African popular cultures represent "non-Western otherness" are almost absent. ${ }^{1}$ The few existing works mainly focus on the representation of what we could define as an internal, African "Other", and investigate media discourses on racism, autochthony, religious and ethnic discrimination among different African groups (Danso and McDonald 2001; Mano 2015; Nyamnjoh 2010) while marginalising the analysis of the way non-African people and cultures from other regions of the "Global South" are represented and discussed in African public spheres. ${ }^{2}$ Nevertheless, with the tremendous increase of popular media production that

\footnotetext{
${ }^{1}$ When using the term "popular" in this article, we refer to the existing literature on African popular arts and media developed by a number of scholars in African studies over the past few years (cf. Barber 1997; Wasserman 2011).

${ }^{2}$ South Africa is an exception in this context, and some research on the media representation of other nonWestern people and cultures have been conducted over the past few years. See for instance Baderoon (2002) and Huynh (2008).
} 
the introduction of digital technologies has fostered, new African images of the non-Western "Other" are emerging, and new imageries are being shaped thanks to the wide circulation that this type of media manages to achieve among local audiences. If the southern Nigerian video film industry (Nollywood), with the hundreds of films it puts on the market every year, is probably the best known vector for the circulation of these new forms of imagery across Africa (Krings and Okome 2013; McCall 2007), ${ }^{3}$ other popular film industries are emerging all over the continent, participating in the creation and circulation of popular media representations of "non-Western otherness" in Africa.

This paper intends to look at this emerging phenomenon by focusing on one of the most dynamic video film industries to have emerged over the past few years, the Ethiopian one (Jedlowski 2015; Thomas 2015). Within the large repertoire of audio-visual materials that this industry has produced since its birth, a small number of films featuring (non-professional) Chinese (or more generally East-Asian) actors in leading roles have appeared. Among them,

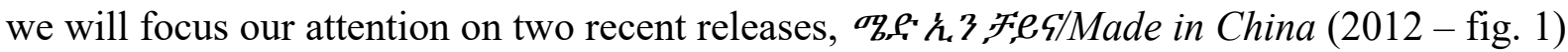
and HGG/Zeraff (2011 - fig. 2), in order to describe and interpret the representation of the Chinese "Other" that these films propose, and the role that this representation acquires within a specific political and cultural context such as the Ethiopian one. Both films were shot at roughly the same time with Zeraff released in the private cinemas in Addis Ababa late 2011 and Made in China following in early 2012. Both films proved extremely popular with the local, Addis Ababa movie-going public, with Zeraff enjoying a run of over four months whilst Made in China was one of the most popular films of the year with it still being screened up to eight months after its release (Mesfin 2014; Naod 2014). Unlike other recent films that feature Chinese characters in cameo-roles (such as in the comical appearance in a scene of pong 7 7.?,e 2/Men's Affair 2 [2009], as a Chinese Ambassador character in the action-thriller

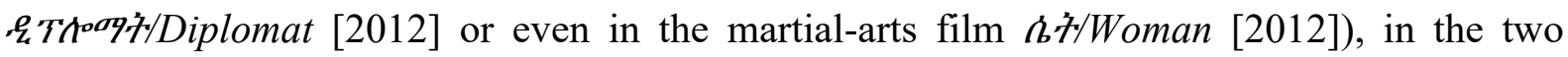
films this paper will analyse, the Chinese characters are central to the narrative of the stories portrayed. ${ }^{4}$

\footnotetext{
${ }^{3}$ Examples of Nollywood films focusing on the representation of non-African non-Western cultures and people are J.U.D.E (Osakwe 2012), partly shot in India, and Kalybos in China (Asamoah 2015), partly shot in China.

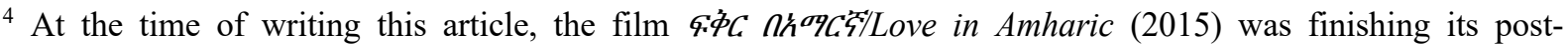
production. This film features the non-professional Chinese actor, Kian Zian, also in a central Amharic-speaking role as the male love interest.
} 
In order to better frame our discussion, and before analysing Made in China and Zeraff and exploring what these films propose in their representations of Chinese people and their presence in Ethiopia, in the first part of this paper we will briefly provide some information about the context from which these films have emerged. This section will focus particularly on the recent history of Chinese presence in Ethiopia, and on the Ethiopian mediascape and the transformation it has witnessed over the past decade thanks to the emergence of the local video film industry. In the second and third parts, we will discuss the two films, analysing their content with the help of a few direct interviews with members of both film crews. Finally, in the fourth part, we will discuss the ambivalent representation of Chinese people that these films produce and connect it with wider debates about the representation of otherness in popular media. In methodological terms, we will look at these films combining film content analysis, sociological and political insights based on our fieldwork experiences in Addis Ababa over the past few years, and the data collected through a number of open and semi-structured interviews with the films' directors and members of the crews. ${ }^{5}$

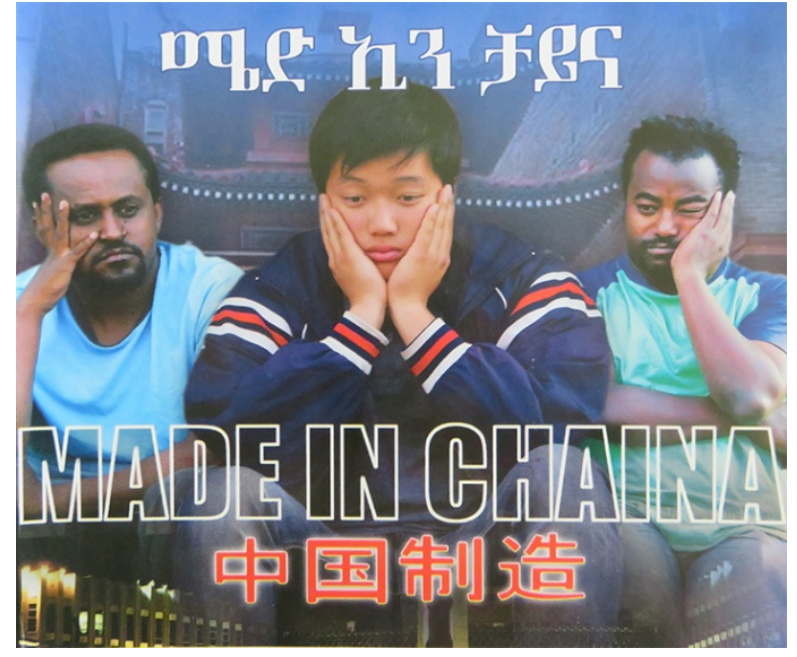

Fig. 1: The jacket of Made in China's VCD

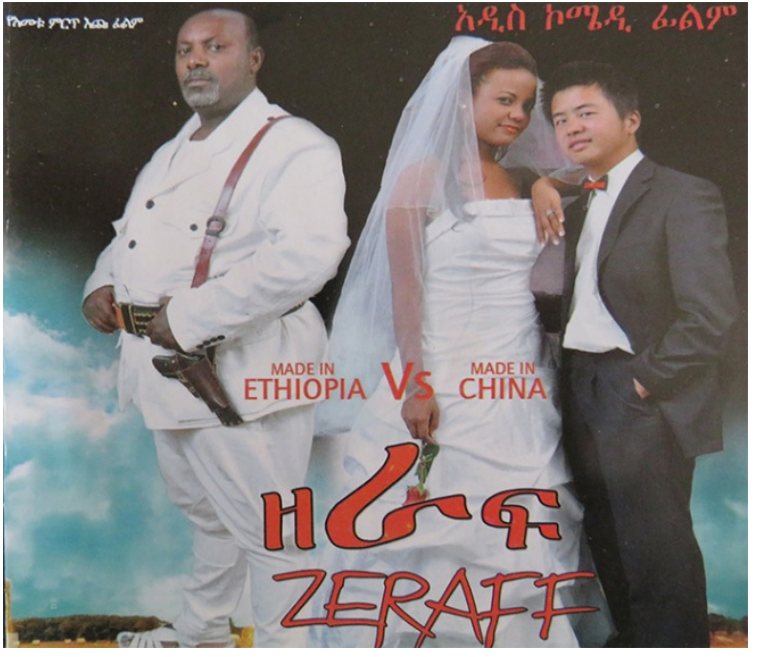

Fig. 2: The jacket of Zeraff's VCD

\section{Drawing the contexts}

As for many sub-Saharan African countries, political and economic relationships between Ethiopia and China have exponentially increased over the past twenty years, reversing a previous trend of diplomatic distance (Adem 2012). Official ties between the two countries

\footnotetext{
${ }^{5}$ Alessandro Jedlowski conducted three months of research fieldwork in Ethiopia between November 2013 and February 2014 as part of his post-doctoral research project, while Michael Thomas has spent time in-and-out of Ethiopia since 2010, with the research for this paper conducted during a six month stay between March and September 2014 for his MA thesis.
} 
were inaugurated in 1970 (Geda 2009), but the relationship remained relatively cold during Mengistu Hailemariam's regime, which favoured stronger connections with the Soviet Union. Under the leadership of Meles Zenawi and the Ethiopian People's Revolutionary Democratic Front (EPRDF) Ethiopia and China began to develop closer relations, and today China is one of Ethiopia's key economic partners (Geda 2009; Thakur 2009). Within this context, the Ethiopian government's fascination with the People's Republic of China is not only connected to the economic opportunities that this country offers to its partners, but also to the political model it proposes, a blend of authoritarianism and economic liberalism that matches the EPRDF's vision of Ethiopia as a centralised authoritarian developmental state.

With the exception of a few, relevant studies on the role of Chinese companies, and more generally of the Chinese model, in shaping the Ethiopian media and telecommunication sector (cf. Gagliardone 2014), most of the existing studies on China-Ethiopia relationships focus on the economic impact of the partnership between the two countries and are generally based on the analysis of macro-economic data. Hence, there has been little interest in the sociological and cultural consequences of the increased connections and exchanges between these two countries. This in many ways reflects the general situation of the existing scholarship on Africa-China relationships, within which studies on the cultural implications of the growing involvement of China in the African continent have been, until recently, limited in number, and have begun to emerge as an autonomous corpus of studies only over the past few years (cf. Banda 2009; Rønning 2014; Shen 2009).

As emphasised by Fackson Banda (2009: 356), China's involvement with African media has been particularly focused on supporting state-owned corporations, thus implicitly consolidating media centralisation and making an attempt at positively influencing the representation of China in local media. Parallel to this, a number of Chinese media corporations have begun to invest in Africa in order to create opportunities for African audiences to access Chinese news and media products (Gagliardone 2013; Xin 2009). A fairly similar landscape can be observed in Ethiopia, where Chinese interventions in the media sector have contributed to the establishment of a rigidly centralised media environment, within which images about China and the Chinese presence in Ethiopia tend to be controlled by local government authorities. Within this context, it becomes relevant to investigate what kind of representations of the Chinese presence in Ethiopia circulate through unofficial, popular media, and how representations are perceived by local audiences and local authorities. In fact, as shown by a number of reports (cf. Geerts, Xinwa and Rossouw 2014), and suggested by a few incidents around Africa over the past few years (including the much 
talked about Abole incident in Ethiopia during which nine Chinese nationals were killed and seven were kidnapped - French 2007), the perception of China's presence in Africa is complex and dynamic. It changes over time and is influenced by a large number of factors that reflects the active role of both Chinese and African people in shaping Africa-China relationships. In this sense, as Fackson Banda suggests, analysing the perception of China's presence in Africa

requires much more nuance than the 'hardware' approach assumed in crude political economy; we need to understand the 'software' of Chinese renewed penetration into Africa. Such a perspective considers both China and Africa as agents, actively engaged in constructing a new cultural milieu. In other words, the question should not only be about what the so-called Chinese dragon is doing to Africa, but what China and Africa are doing together (2009: 355).

Taking up this suggestion, in this paper we make an attempt at addressing some of these questions through the analysis of a specific popular culture form, that is, Ethiopian popular commercial films in digital format.

As mentioned above, over the past decade a thriving digital film industry has emerged in Ethiopia's capital Addis Ababa. It produces commercially-driven films, uses Amharic as its main language and targets local and diasporic audiences. These films are firstly released in the large cinema theatres that characterise Ethiopian main cities' urban landscapes, and later circulate via VCDs and internet, thus participating in the creation of an arena of debate concerned with present-day Ethiopian reality, which is alternative to the one state-controlled media try to impose.

Despite having to go through state-run control panels in order to obtain exhibition licences, the contemporary film industry is vastly different to that of the state monopolised film sector which came before. Since cinema's introduction to Ethiopia in 1897, at the bequest of Emperor Menelik II, celluloid film production and exhibition has depended on state benefactors for support. The state's interest in film production, distribution and exhibition was at its most pronounced during the rule of the military junta, known as the Derg, from 19741991. The Derg, with explicit Soviet support, bought into cinema's capacity as propaganda, which resulted in strict controls on the exhibition and production of films in Ethiopia. The creation of a government funded film division within the Ministry of Culture and Sports (which developed into the Ethiopian Film Corporation in 1986) ushered in an age of increased investment in filmmaking, vastly increasing Ethiopia's filmic output (prior to the Derg, only two feature films were produced from within Ethiopia, by 1979 the state had produced 24 documentaries and a docu-drama). After coming to power in 1991, the EPRDF deemed film 
production an unnecessary and unprofitable state venture which resulted in the withdrawal of state support for film production, whilst maintaining control of film exhibition on ideological grounds. The void left in film production in Ethiopia was filled by entrepreneurial theatre groups, local video and music distributors and state-television professionals who noticed the potential in producing video films in Amharic, Ethiopia's lingua franca. The commercial potential of locally produced films, however, was not fully realised until the government lifted a licensing requirement which stipulated films be exclusively projected by using the standardised $35 \mathrm{~mm}$ film gauge, opening up for committed individuals to attempt screenings of video films in cinemas. Breaking from the history of state controlled cinema in Ethiopia, this contemporary, quasi-liberalised film sector has produced a relatively independent sphere of media production emanating from entrepreneurial individuals with variable filmmaking knowledge prior to embarking on projects.

\section{Parody and social criticism in Made in China}

Made in China's narrative follows the escapades of two Ethiopian friends (Solomon and Johnny) and a Chinese man (known by his Ethiopian name, Abulé) as they try to swindle money from local Ethiopians in order to afford a trip and visas to China with the aim of setting up a business in Ethiopia selling cheap Chinese goods. Solomon and Johnny first meet Abulé when he is moving into their neighbourhood soon after his release from an Ethiopian prison, having completed a five year sentence for being involved in a (Chinese construction) corruption scandal. Solomon and Johnny offer to move Abulé's belongings but are deterred by Abulé's martial arts posturing (as he knows he would have to pay them for their help). After a scuffle with a local tough guy the two Ethiopians seek help from Abulé who, unable to actually fight, runs-off seeking shelter in a local t'illa bet (drinking house serving a traditional home-made beer), with the two friends managing to escape with him. After drinking t'illa together, it is apparent that Abulé can speak fluent Amharic and even knows Addis street language (yä'arada qwanqwa) and parables (tärät-ïnna mïsalé), at this point the three become good friends and spend what little money they have during a night-out on the town. In desperate need of money the three hatch consecutive scams which involve playing on Ethiopian stereotypes and pre-conceptions of Chinese people. Eventually the three friends are wanted by the police for their cons, but as Abulé falls in love with a local Ethiopian girl, he brashly decides to follow through on their last job - to build a new road for a local neighbourhood. 
The comedy in the film is structured around parodying the Ethiopian-Chinese relationship and addressing misnomers and stereotypes popularly held by Ethiopians who believe foreign workers are better than Ethiopian ones (Mesfin 2014). The crucial character, then, is that of Abulé, who is actually played by the non-professional South-Korean born actor, Young-Guk Lee, a university student in Addis Ababa University at the time when the film was shot. Son of a Korean missionary, Young-Guk Lee moved to Addis Ababa with his family when he was ten years old and thus picked up the Amharic language and Ethiopian customs at a young age (Lee 2014). Lee's ability to speak Amharic and natural comic skills are key to the central parody of the film which sees the Chinese character imbued with Ethiopian mannerisms. Adding to the irony and the comic effect of the film is the fact that when the three friends are on a scam, Abulé must pretend that he cannot understand Amharic and play the stoic, presentable Chinese man which he inevitably struggles to pull off. An example of this is when he corrects his friends' mistakes (in Amharic) when they present their business plans, or when he says "yemaräsh" (bless you) when he hears sneezing. As one of the film's directors pointed out in the interview we had with him, the fact that Young-Guk Lee is South Korean had no effect on the audience's reaction to the film (Mesfin 2014). Rather, one could say that it somehow confirmed the existing stereotype circulating in Ethiopia which associates all East-Asian people with China. Even Lee's appearance on many Ethiopian talk shows and interviews with him stating his Korean origin did not modify the popular perception of him being Chinese, something that, as he underlined in interviews, constitutes one of the most common irritating experiences for him in Ethiopia (Lee 2014). ${ }^{6}$

Made in China's plot relies on the three scams staged throughout the narrative to maintain its parody of how Ethiopians popularly perceive and often naïvely trust foreigners on facevalue. The three business idea-like scams that Abulé, Solomon and Johnny try to enact are deeply based, as Mesfin (2014) underlines, on broader popular conceptions of the type of businesses Chinese people successfully run in Ethiopia, and in this sense they interestingly reveal the way Chinese people are "stereotyped" in the Ethiopian public discourse (cf. Hall 1997). Mesfin points out that a lot of these businesses are rooted in traditional Chinese culture, such as the acupuncture and traditional Chinese medicine clinic that the friends open first, and the martial arts school they open later on. It is the first of these con operations, the

\footnotetext{
${ }^{6}$ It should be noted that this phenomenon does not only occur with foreigners from South East Asia but, increasingly, also with Western foreigners. This calling of any foreigner "China, China" somehow points to the growing impact of Chinese presence in Ethiopia on popular perceptions of foreigners, which used to be addressed by the use of the term ferenji (European foreigner).
} 
Chinese medical clinic, which is pulled off with most comic effect in the film, as the friends have to hide their faces under surgical masks when the previous tough guy who chased them in the opening of the film enters for treatment. The treatment they recommend is acupuncture and after making sure that the patient is thoroughly tied to a table, they somewhat sadistically start to stab the man with pins, inducing further pain and cries of agony (Fig. 3). The tough guy then manages to break out of his bonds and proceeds to chase the three friends out of the clinic, reflecting the earlier sequence when Abulé was unable to do martial-arts. This time however, their first scam is also exposed. The parody here is highlighted further as the tough guy is further injured after he goes around looking for Abulé in the first instance and unwittingly confronts a Chinese man in a similar track-suit to Abulé's. Unlike Abulé in the previous scene, however, this time the Chinese man instantly floors him with martial-arts, thus harking back to the old stereotype that all Chinese people know martial-arts.

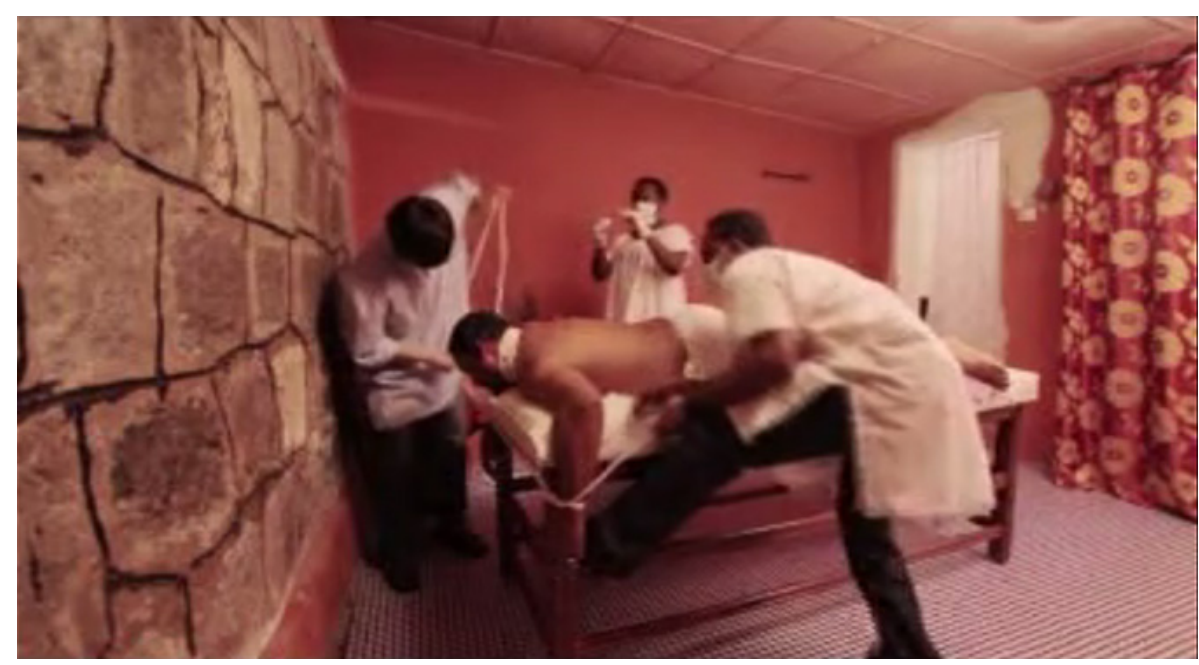

Fig. 3: The acupuncture scam

Perhaps, through the second business-con, that of opening a construction office, Made in China more evidently verges on social satire rather than parody. The construction sector in Ethiopia has become associated with the Chinese labourers that are sent into the country in order to construct major infrastructure projects such as highways, railways and more recently commercial and residential buildings. In Mesfin's words, "Made in China observes and reflects the reality", this reality being that the Chinese labourers are competing directly with Ethiopians and therefore hindering employment in the country (Mesfin 2014). The construction office scam also neatly brings together the other narrative strand of the film which follows a socially conscious Ethiopian man asking his neighbours whether they will help contribute in order to build a new road for their area. Through different sequences this 
narrative builds up the complex issues of distrust and individualism amongst neighbours in urban Ethiopian communities. Not only is the socially conscious man rudely turned away by everyone he asks for donations, but in a sequence where he is cleaning out the road's gutters single-handedly, he stares in disbelief as a fellow neighbour relieves himself into the ditch he has just cleaned. When Abulé and his friends advertise a road-construction meeting for the same community, being held by the Chinese "Engineer Young" (Abulé), the whole community turns out and supports with exuberant donations. This somewhat blind trust of foreigners is a popular critique of Ethiopia which is represented throughout Made in China. Other moments where this occur (and which also instigate rapturous laughter in the cinema) are when Abulé, being foreign, does not get searched when he passes through a security check whilst his two Ethiopian friends pass through behind him and disgruntledly object to getting immediately frisked. The Ethiopian mentality is also questioned as the first patient to receive treatment from Abulé's clinic, although accidently being pushed off the examining-bed, believes he is fully cured by the foreigner's unorthodox methods. It is in these many scenes and the joining together of the two narrative strands, apparent when the socially conscious Ethiopian attends the meeting of "Engineer Young", in which the comical elements and critical elements of social satire start to become obvious, and the analysis of the broader relationships between Chinese and Ethiopians in Ethiopian society is made more explicitly visible.

When asked precisely about this relationship, Mesfin spoke about the sense of anxiety that the rapid expansion of Chinese activities in the country has provoked among many Ethiopians: "We have to respect the people who are coming in to help transform the system, but we don't have to let them control everything" (Mesfin 2014). And it is the idea of the need of mutual respect between the Ethiopian community and the Chinese workers that seems to be the message that Made in China ends on. A possibly calamitous confrontation between the Ethiopian neighbours and Abulé and his friends is averted as Abulé is shown walking up the road in his hard-hat, leading a group of Ethiopian workers. The angry community soon realise Abulé's genuine intentions and use the tools they had picked up in order to harm Abulé, instead, in order to co-operate in the construction of their road.

\section{Political critique and the symbolic use of Chinese otherness in Zeraff}

The title of the second film we focus on, Zeraff, comes with deep Ethiopian patriotic ideals as opposed to the world renowned label of Chinese manufacturing, "made in China", of which Made in China clearly takes its name. The word zeraff does not have a literal translation in 
English but it is used almost uniquely within a certain genre of Amharic oral poetry called fukkära ïnna qärärto (recitals of heroic deeds and war songs). The word can thus be interpreted as meaning "he who slays with a sword", or "he who is a defender/killer" which sets out the oppositional binary codes and melodramatic caricatures which dominate the style of the film.

Zeraff's plot centres on the father-daughter relationship of Ïndäshäw, a man who suffers heart palpitations and panic attacks when he comes into contact with anything from China, and Adän, a young woman depicted as naïve and self-centred. The opening sequences establish that Ïndäshäw's trauma was instigated after his father was killed by a faulty Chinesemade electricity generator during a power-cut, a premise that, while pointing at one of the most pervasive stereotypes about Chinese goods in Africa (their bad quality and faultiness), contributes to making the following scenes farcical. We quickly see Adän meeting a Chinese man called Po (humorously nicknamed Po-Po, meaning ‘potty' in Amharic, by Ïndäshäw) and despite them being unable to communicate with each other and the fact that Adän is in a long term relationship with an Ethiopian, Po proposes to her and she accepts with child-like clapping of the hands in delight. She proceeds to tell her father the good news but hides the fact that her new fiancée is Chinese. After Ïndäshäw arranges for elders to deal with the marriage proposal, Po also turns up at the house. Only after seeing Adän rushing to hug Po does Ïndäshäw realise that his daughter has accepted a marriage proposal from a Chinese national, a thought which triggers his blood pressure to raise too high leading to him passingout (Fig. 4).

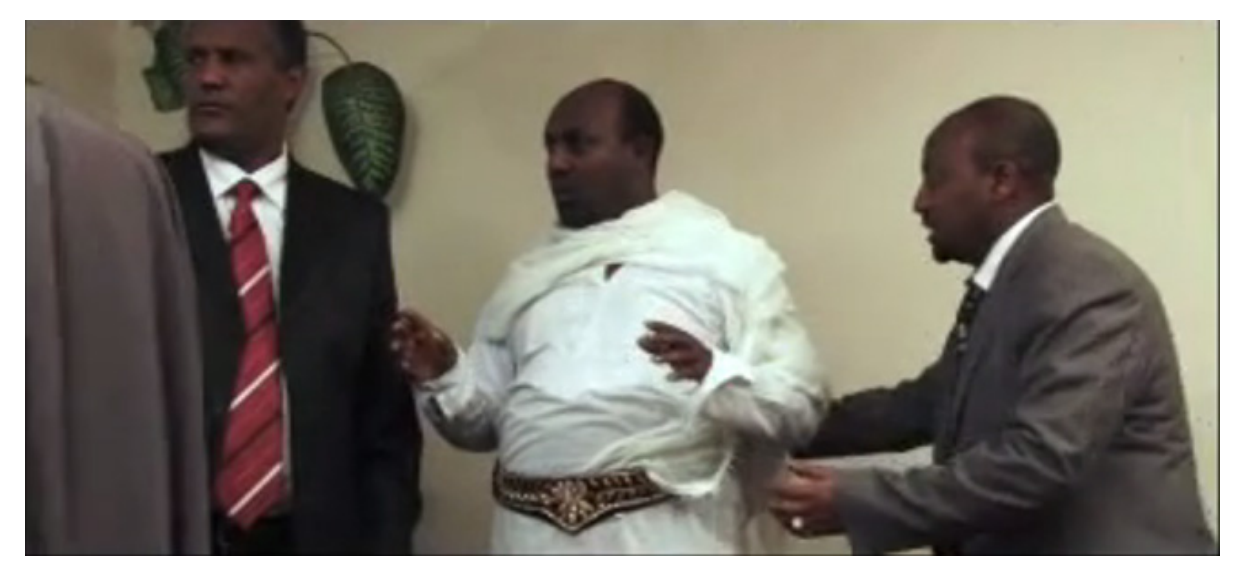

Fig. 4: Ïndäshäw passing out after seeing Po

The farce continues when it occurs that Ïndäshäw has been in a coma for three months with intermittent bouts of delusionary fukkära recitals. When he is omitted from hospital, however, 
the ever naïve Adän, takes him home to proudly reveal a photo of her and Po in a wedding style pose which instantly instigates another bout of Ïndäshäw's illness. Despite his attempts to sabotage the marriage, Ïndäshäw finally accepts Po due to Adän becoming pregnant, but in order for Po to prove himself he compels the Chinese character to carry out three acts, which include drinking thirty two bottles of tejj (a traditional honey mead which killed one of Ïndäshäw's friends who attempted twenty seven bottles), chopping up fire-wood and making the traditional bread-like staple, ïnjära, the foundation of Ethiopian cuisine. The performance and particular significance of these acts create scenarios of comical interaction between Po and Ïndäshäw. For instance, when Po fails to make injära correctly, not realising that it is regarded as a woman's job, he asks Ïndäshäw to show him how to do it which offends him to such a point that Ïndäshäw draws his pistol on the bemused Po. Po's translator then persuades Ïndäshäw to give Po tasks that can prove his manliness and Po finally proves his worth when, at Ïndäshäw's bequest, he defeats his belligerent nephew in one Kung-Fu style punch. These scenes all play on reciprocal stereotypes and misunderstandings which, while somehow perpetuating essentialist perceptions of Chinese otherness, equally mock them, pointing out the naivety of many Ethiopians' imagery of Chinese people and culture.

Ïndäshäw is presented throughout the film as an Ethiopian patriot, always wearing traditional white garb and even a patriot's uniform (see fig. 2 and 4), offering constant praise to the past great Emperors of Ethiopia at a shrine to Emperor Tewodros II located near the door of his house. In Ethiopia, Tewodros II is regarded as the most heroic Emperor because he took his own life rather than suffer humiliation at the prospect of being taken prisoner at the hands of the British expeditionary force in 1868. Ïndäshäw's veneration of Tewodros II is not uncommon within nationalistic Ethiopian households. These traditional Ethiopian characteristics are epitomised when Ïndäshäw directly references Tewodros' heroic deeds when he addresses the Emperor's portrait and states that he feels guilty that Tewodros gave his life for the new Ethiopian generation that are out of touch with their own tradition and history. Ïndäshäw is also very traditional in how he converses with other characters and how he seems to be stubbornly set in his ways, adamant that his father's death is a result of a faulty Chinese generator, incapable of entertaining the thought that perhaps the frequent power-cuts in Addis are also partly to blame. In contrast to Ïndäshäw is his daughter, Adän, who is always wearing colourful clothes, jeans and earrings. Her mannerisms and speech, in particular, are a whirlwind of drabble and inconsistent thought, she seems perpetually confused and can be identified as inhabiting a hiatus in modern Ethiopian society between the local Ethiopian-Amharic worldview and a more global, liberal outlook. The Chinese 
character, Po, is then introduced in order to explore the relationship between Ïndäshäw and his daughter.

The comedy instigated by the ensuing "culture clash", enables the film to covertly critique the generational dislocation within the burgeoning middle-classes of Ethiopia, a clash within which the presence of the Chinese character, Po, seems somehow to symbolise an external model of non-Western globalisation and modernisation naively and unconditionally adopted by Adän/the youth (and, as a matter of fact, by the government, who has developed intense political and economic ties with China), while being thoroughly and at times violently resisted by Ïndäshäw/the elders (representatives, in the film's narrative, of the nationalist ideal of unity and cultural integrity that the EPRDF's government is often accused by its opponents to have abandoned in favour of ethnic federalist policies - see Turton 2006). Unlike with Made in China, then, the exploration of the Ethiopian-Chinese relationship in Zeraff seems to be instrumental in an entirely different narrative objective, that of criticising some aspects of the current political situation in Ethiopia. As a result, little interest is devoted to the exploration of the Chinese character, whose function is more symbolic than narrative. Po is in fact played by a non-professional Chinese actor (Lan Zhi) who had no prior acting experience and little ability to communicate in English, let alone Amharic. The character is represented more as an object and symptom of the influx of foreign influences on Ethiopia which the film uses to explore Ethiopia's inability to develop, adapt and grow on its own terms. This more inward critique of Ethiopian society is what the film director refers to when mentioning that "nothing in Zeraff is about Chinese at all. It just seems that way because that is the only way we can express..." (Naod 2014).

Following on from this, it is also apparent that unlike Made in China, within Zeraff, the genuine feelings or intentions of the Chinese character are never questioned. Throughout most of the film Po seems to be presented as an innocent bystander who is caught between two oppositional representations (Ïndäshäw and Adän) of Ethiopian society's generational schism. Towards the dénouement of Zeraff, it even becomes apparent, through Po's success at passing all the "traditional Ethiopian" challenges, that he and Ïndäshäw are able to communicate better with each other than can Adän and her brother with Ïndäshäw (their father). This generational dislocation is further apparent in the closing scene which depicts Po finally being accepted by the elders when Ïndäshäw's son, without prior warning, announces his engagement to a Chinese woman - at which point Ïndäshäw passes out again.

\section{Censorship, social criticism and the representation of the "Other"}


As the brief analysis of the two films highlighted, both Made in China and Zeraff represent and use Chinese characters in order to engage with alternative social critiques. In this sense, in both films, the representation of "otherness" is functional to the discussion of specific, inward looking political and social issues, and it thus has, in many ways, less to do with the Chinese "Other" than with the Ethiopian "Self". It is a representation that is, inevitably, "exterior" to the object it represents (the Chinese character) in ways similar to those Edward Said (1978: 20-21) pointed out when defining the "exteriority of representation" typical of Orientalist discourses. As Orgad puts it, discussing Said's work, "Orientalism is related less to the Orient than to 'our' Occidental world. The Orientalist is not concerned with the Orient except as the motivation for what s/he says" (2012: 32). In this sense, it is no surprise that Ethiopian films focus predominantly on local complexities that resonate with producers and main target audiences, tending to produce rather stereotypical representation of the non-Ethiopian "Other". As little time is invested in exploring the social, cultural and psychological nuances of characters emerging from different cultural and racial backgrounds (in this case Chinese) these films can be seen to be repeating an attitude well established in major film industries around the world (cf. Higgins 2012; Naficy and Gabriel 1993). Even if simplistic representations of the "Other" are perpetuated due to the limited resources available and to the specific constraints affecting production processes, one can consider the casting decisions made in the two films analysed here as good examples of this attitude. For the roles of the Chinese characters, the casting agents opted respectively for a Korean non-professional actor (Made in China) and a non-professional Chinese actor unable to speak Amharic or English (Zeraff) in a film in which there are no lines in Mandarin. Both cases end up reinforcing the overall feeling that the filmmakers and producers had no particular interest in proposing an accurate representation of Chinese people in their films.

So far, then, at least in its guiding strategies, the representation of "otherness" in Ethiopian popular media seem to somehow repeat some of the recurring limits that cultural studies and postcolonial studies have underlined when analysing Western discursive constructions about "otherness". A specific aspect of Ethiopian, and particularly Amharic artistic tradition should, however, be considered in order to gain a better understanding of the narrative strategies deployed in the films discussed in this article. In fact, multi-layered narrative structures that address a particular subject in order to point at something else are common in Ethiopian, and particularly Amharic, literature and culture. They are often referred to through the use of a term that comes from the ancient tradition of oral Amharic poetry: säm-ïnna wärq (wax and gold). In the words of the Ethiopian film scholar Teshome Gabriel, 
The term refers to the 'lost wax' process in which a goldsmith creates a wax form, casts a clay mould around it, then drains out the wax and pours in molten gold to form the valued object. Applied to poetics, the concept acknowledges two levels of interpretation, distinct in theory and representation. Such poetic form aims to attain maximum ideas with minimum words. 'Wax' refers to the most obvious and superficial meaning. But the 'gold' embedded in the artwork offers the 'true' meaning, which may be inaccessible unless one understands the nuances of folk culture. [...] To restore the 'gold' in its purity [...] means, therefore, to perform an autopsy to remove the 'wax,' the comedy format, in order to gain access to the text's ideology (1982: 31$)$.

As demonstrated by a number of researchers who adopt this epistemological approach in order to analyse contemporary Ethiopian (and in some cases also more generally African) art and culture (cf. Gabriel 1982; Klemm and Niederstadt 2009), the "wax and gold" formula is not only something that belongs to the ancient tradition of monastic schools of Ge'ez language where it used to be taught (Levine 1972). On the contrary, many argue that it "embodies [a] fundamental indirection in speech by means of a studied use of ambiguity [which] colours the entire fabric of traditional Amhara life [and which] provides the one outlet for criticism of authority figures in a society which strictly controls every kind of overt aggression toward authority" (Levine 1972: 8, 9). As referred to by many Ethiopian filmmakers, the structure of films remain relatively linear and clear, reflecting the structure of traditional storytelling or tärät which renders moral and didactic dénouements easy for all to comprehend. Within these narratives, however, a form of wax and gold remains, Behailu Wassie describes a wax and gold in Ethiopian films as embodying "the body and the soul, whereas the body is clear for all to see, it is the spirit [moral messages of the film] which demands closer attention and deeper appreciation" (Behailu 2016).

Incidentally, it is important to underline that, while censorship is formally prohibited by the Ethiopian constitution approved in 1994 (article 29), the state developed an articulated institutional system to monitor the content and circulation of films. As briefly mentioned previously, once the production is completed, a film has to obtain a license from the Film License and Regulation Bureau of the Culture and Tourism Office of the Addis Ababa City Council, which has the official mandate of controlling the way in which issues related to ethnicity, religion and sexuality are represented in films, but which also implicitly exercises a form of political censorship on the films being screened. This rigid licensing system is oriented toward protecting the delicate balance between the different ethnic and religious groups that compose the fabric of the Ethiopian nation. But it has also permitted the Ethiopian authorities to make their presence strongly felt among film directors and producers since the early years of the video production phenomenon, indirectly pushing for the adoption of wax 
and gold-like narrative structures within films. It is within this context that we can better appreciate the above-mentioned quote from Zeraff's film director saying that "nothing in Zeraff is about Chinese at all. It just seems that way because that is the only way we can express..." (Naod 2014).

The adoption of a multi-layered structure of meaning, however, does not automatically protect film producers and directors from censorship and government control. In the case of Zeraff, for instance, it seems that the "wax" layer has been read by some as the "gold" of the film's meaning, thus generating what, following Umberto Eco (2003 [1972]: 4), we could call an "aberrant decoding" of the film. Zeraff in fact provoked indignation among government officials in reaction to the bad attitude toward Chinese nationals it seems to convey. As one of the members of the film's crew told us in an interview,

The first time we tried to do a commercial through Ethiopian radio, they said, 'no, we can't do this commercial because the movie doesn't support the Chinese people here, because [...] in the movie, Showaferew's character [Ïndäshäw] asks the Chinese character to go back to his county, to go back to wherever he came from, to just leave us alone. And since the Ethiopian government wants the Chinese to come and live amongst Ethiopian people, they don't want this because it is opposite to what they are saying (personal communication, 2014).

As a result, Zeraff provoked critical reactions which eventually lead to the film being withdrawn from cinemas. The government's reaction is characteristic of a rigid bureaucratic culture, in which a stereotypical interpretation of a film by public authorities falls back on pre-defined categories, thus overlooking subtle nuances and inward criticisms. The focus on "Chinese Otherness" here is intended to expose and critique the "Ethiopian Self", in order to reflect on its own contradictions in ways that a more loaded and historically burdened "Western Other" may not permit. But, through their contrivances, the authorities (unwillingly or as a result of a bureaucratic rigidity) end up fighting this pluralism in an attempt to maintain the status-quo by reinforcing ideas of rigid identities and behaviours.

The government's reaction points also to the fact that, despite the implicit intention of expressing precise criticisms about Ethiopian society, both films analysed in this essay also produce representations of the Chinese "Other" which can easily risk being misunderstood as amplifications of stereotypes and popular negative perceptions of China's presence in Ethiopia. This brings us back to where we started this section, and thus to a critical appraisal of the strategies adopted when non-Ethiopian people (and in some cases, also simply nonAmhara Ethiopian people) are represented in Ethiopian popular films, and the place that the presence of these people is allowed to occupy in the imagined identity of the Ethiopian nation. 
As pointed out by Achille Mbembe (2010), with the partial exception of South Africa, most sub-Saharan African countries' contemporary discourses on national identity exclude racial multiplicity, ${ }^{7}$ implicitly negating the possibility of existence of, for instance, a Chineselooking Ethiopian person. ${ }^{8}$ As predicted by Frantz Fanon, the universalistic call for liberation of anti-colonial movements has not managed to resist the fascination for racially based definitions of national identity, producing an itinerary that has progressively moved "to ultranationalism, to chauvinism, and finally to racism" (Fanon 1990 [1968]: 125, quoted in Ndlovu-Gatsheni 2009: 63). In this sense, around the continent, definitions of "Africanity" and, more specifically, national identity tend to be closed rather than open. As Francis Nyamnjoh has underlined, a number of important questions seem to have been progressively erased from the ongoing debates on identity and belonging in Africa:

If belonging is a process, then the idea of the social construction and dynamic nature of Africa has to be taken seriously, both by the media and by those studying racism and ethnicity in Africa. What does it mean to be African? Who qualifies to claim Africa? Is being African or claiming Africa an attribute of race and skin colour (black, white, yellow), birth (umbilical cord, birth certificates, identity cards, passports), geography (physical spaces, home village), history (encounters), culture (prescriptive specificities), economics (availability and affordability, wealth and deprivation), sociology (social configurations and action, inclusion and exclusion), psychology (mindsets), philosophy (worldviews), politics (power relations), collective memory (shared experiences and aspirations) or a category through which a world that is not rigidly geographical, racial or cultural is constructed, to name just a few of the many possibilities? (Nyamnjoh 2010: 75)

In Ethiopia these issues resonate within multiple layers, all rconnected to the specific complexity of the ethnic, religious and racial composition of Ethiopian society and the historical and contemporary conflicts relating to it (cf. Aalen 2011; Baxter et al. 1996; James et al. 2002). Nevertheless, this does not undermine the fact that the definition of "Ethiopianness" (and, in a larger sense, of Africanity) that these films implicitly convey is closed and based on racial attributes. This is demonstrated for instance by the fact that much of Made in China's humour is constructed precisely on the racial definition of autochthony, with many of the film's jokes revolving on the surprised reaction of Ethiopian people to Abulé's markedly Ethiopian attitudes and linguistic skills. The irony plays precisely on the popular assumption that a Chinese-looking Ethiopian national cannot exist.

\footnotetext{
7 See, however, Christopher Lee (2014), Carina Ray (2015) and Rachel Jean-Baptiste (2011) for historical examples that highlight the existence of more complex scenarios, particularly during colonial times.

${ }^{8}$ This problem is further accentuated in Ethiopia by the fact of it being mandatory that each individual carries an ID card which, among other primary information, denotes a person's ethnicity.
} 
In fact both films humorously point at, and somehow reassert this principle, proposing a somehow ambiguous answer to our initial question about the representations of otherness in Ethiopian popular media: while the Chinese presence is seen as having both good and bad consequences on the Ethiopian economy and society, Chinese people represent a form of cultural and racial otherness which is far from being accepted as part of the imagined Ethiopian "Self". There is probably nothing particularly surprising about this as it is commonly noted that most nations in the world struggle to accept racial multiplicity as part of their collective, imagined identity. Nevertheless, this points our attention toward a number of dimensions of China-Africa relations, connected to terms such as race, identity and belonging, which have received little scholarly attention in the past, and which could become relevant in the years to come as a result of the growing number of Chinese migrants settling on African soil.

\section{Conclusion}

As Stuart Hall would put it, "symbolic boundaries are central to all culture. Marking 'difference' leads us, symbolically, to close ranks, shore up culture and to stigmatize and expel anything which is defined as impure, abnormal. However, paradoxically, it also makes 'difference' powerful, strangely attractive precisely because it is forbidden, taboo, threatening to cultural order" (1997: 237). There is then something inherently ambiguous about the role of otherness within the collective imagination. While its image is generally based on a "binary form of representation [...] - good/bad, civilized/primitive, ugly/excessively attractive, repelling-because-different/compelling-because-strange-and-exotic", the "Other" is implicitly "required to be both things at the same time!" (Hall 1997: 229, original emphasis). Popular representations of otherness are, therefore, constructed from a mixture of repulsion and fascination, interest and dismissal, something that can be related, in the words of film critics Hamid Naficy and Teshome Gabriel, to "a continual process of yearning - for meaning, for those qualities which the dominant order has exiled or lost, and for the certainties that ideologies provide in a world that is increasingly uncertain and unpredictable. Since the yearning is never fulfilled, the other remains forever alluring (and threatening) [...]. The other tends to thrive on the ambiguities and the limits of language" (1993: XI).

The two films analysed in this paper are imbued with this ambiguity. As our analysis evidenced, their representation of the Chinese "Other" at times criticises and at times reasserts existing stereotypes and prejudices. But, overall, they seem to use Chinese characters mainly 
as narrative devices functional in the development of specific, inward-looking social and political criticisms. This attitude inevitably forces the films to overlook the key issue underlying discourses about otherness in Ethiopian popular media-namely the issue of how to deal with racial multiplicity in a society that defines belonging along rigid and exclusionary terms, where the essentially fluid nature of identity is dismissed in favour of hard, reified constructs which are propagated in the game of identity politics that defines our time.

\section{List of references}

Aalen, Lovise. 2011. The Politics of Ethnicity in Ethiopia: Actors, Power and Mobilization Under Ethnic Federalism. Leiden: Brill.

Adem, Seifudein. 2012. "Imperial Ethiopia's relations with Maoist China”. African EastAsian Affairs 1: 31-53.

Admasu, Kebede. 2009. Pø38年 7,q,e2/Men's Affair 2. Ethiopia: Arki Sera Production.

Asamoah, Koffi. 2015. Kalybos in China. Ghana: Kofas Media.

Awol, Haydrin. 2012. ił/Woman. Ethiopia: King Awol Films.

Baderoon, Gabeba. 2002. "Shooting the East/veils and masks: Uncovering Orientalism in South African media". African and Asian Studies 1(4): 367-384.

Banda, Fackson. 2009. "China in the African mediascape: A critical injection". Journal of African Media Studies 1(3): 343-361.doi: http://dx.doi.org/10.1386/jams.1.3.343/1

Barber, Karin (ed.). 1997. Readings in African popular culture. Bloomington: Indiana University Press.

Baxter, Paul T. W., Hultin, Jan; and Alessandro Triulzi (eds). 1996. Being and Becoming Oromo: Historical and Anthropological Enquiries. Stockholm: Nordic African Institute.

Behailu Wassie. 2016. Interview conducted by Michael W. Thomas. Addis Ababa, March 8 .

Castoriadis, Cornelius. 1987. The Imaginary Institution of Society. Cambridge: Polity.

Danso, Ransford, and David A. McDonald. 2001. "Writing xenophobia: Immigration and the print media in post-apartheid South Africa”. Africa Today 48(3): 115-137.

Eco, Umberto. 2003 [1972]. "Towards a semiotic inquiry into the television message". In Television: Critical Concepts in Media and Cultural Studies, Volume II, edited by Toby Miller, 3-19. London: Routledge.

Fanon, Frantz. 1990 [1968]. The Wretched of the Earth. New York: Grove. 
Foucault, Michel. 1980. Power-Knowledge: Selected Interviews and Other Writings. Brighton: Harvester Press.

French, Howard W. 2007. "Letter from Ethiopia: China's risky venture into resource-rich Africa". The New York Times, May 2.

Gabriel, Teshome. 1982. "Xala: A cinema of wax and gold". Jump Cut: A Review of Contemporary Media 27: 31-33.

Gagliardone, Iginio. 2013. "China as a persuader: CCTV Africa's first steps in the African mediasphere". Ecquid Novi: African Journalism Studies 34(3): 25-40. doi: $10.1080 / 02560054.2013 .834835$.

Gagliardone, Iginio. 2014. "New media and the developmental state in Ethiopia". African Affairs 113(451): 279-299. doi: 10.1093/afraf/adu017.

Geda, Alemayehu. 2009. "Scoping study on the Chinese relation with Sub Saharan Africa:The Case of Ethiopia".Scoping Studies on China-Africa EconomicRelations, (http://hdl.handle.net/10419/93155).

Geerts, Sofie, Xinwa, Namhla, and Deon Rossouw. 2014. Africans' Perceptions of Chinese Business in Africa. Geneva: Globethics.net/Hatfield (Ethics Institute of South Africa).

Hall, Stuart. 1997. Representations: Cultural Representations and Signifying Practices. London: Sage.

Hallam, Elizabeth, and Brian Street (eds). 2013. Cultural Encounters: Representing Otherness. London: Routledge.

Haynes, Jonathan, 2013. "The Nollywood diaspora: A Nigerian video genre". In Global Nollywood: The Transnational Dimensions of an African Video Film Industry, edited by Matthias Krings and Onookome Okome, 73-99. Bloomington: Indiana University Press.

Huynh, Tu T. 2008. "Loathing and love: Postcard representations of indentured Chinese laborers in South Africa's reconstruction, 1904-10". Safundi: The Journal of South African and American Studies 9(4): 395-425.

Higgins, Mary Ellen (ed.). 2012. Hollywood's Africa after 1994. Athens: Ohio University Press.

James, Wendy; Kurimoto, Eisei; Donham, Donald; and Alessandro Triulzi (eds). 2002. Remapping Ethiopia: Socialism and After. Athens: Ohio University Press.

Jean-Baptiste, Rachel. 2011. “'Miss Eurafrica': Men, women's sexuality, and métis identity in late colonial French Africa, 1945-1960". Journal of the History of Sexuality 20(3): 568593. doi: 10.5555/jhs.2011.20.3.568. 
Jedlowski, Alessandro. 2015. "Screening Ethiopia: A preliminary study of the history and contemporary developments of film production in Ethiopia". Journal of African Cinemas 7(2): 169-185.

Kaur, Ravinder. 2002. "Viewing the West through Bollywood: A celluloid Occident in the making". Contemporary South Asia 11(2): 199-209.

Klemm, Peri M., and Leah Niederstadt. 2009. "Beyond wide-eyed angels: Contemporary expressive culture in Ethiopia”. African Arts 42(1): 6-13. doi: 10.1162/afar.2009.42.1.6.

Krings, Matthias, and Onookome Okome (eds). 2013. Global Nollywood: The Transnational Dimensions of an African Video Film Industry. Bloomington: Indiana University Press.

Lee, Christopher J. 2014. Unreasonable Histories: Nativism, Multiracial Lives and the Genealogical Imagination in British Africa. Durham: Duke University Press.

Lee, Young-Guk. 2014. Interview via email conducted by Michael W. Thomas. July 5.

Levine, Donald N. 1972. Wax and Gold: Tradition and Innovation in Ethiopian Culture. Chicago: University of Chicago Press.

Loshitzky, Yosefa. 2010. Screening Strangers: Migration and Diaspora in Contemporary European Cinema. Bloomington: Indiana University Press.

Mano, Winston (ed). 2015. Racism, Ethnicity and the Media in Africa: Mediating Conflict in the Twenty-First Century. London: IB Tauris.

Mbembe, Achille. 2010. Sortir de la grande nuit. Essai sur l'Afrique décolonisée. Paris: Éditions la Découverte.

McCall, John C. 2007. "The pan-Africanism we have: Nollywood's invention of Africa”. Film International 5(4): 92-97.

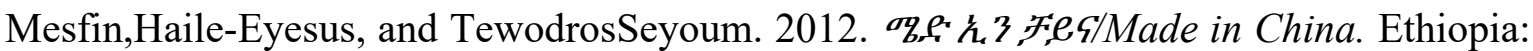
Misalé Film Production.

Mesfin, Haile-Eyesus. 2014. Interview conducted by Michael W. Thomas, Addis Ababa, June 19.

Mignolo, Walter D. 2005. The Idea of Latin America. London: Blackwell.

Mudimbe, Valentin Y. 1988. The Invention of Africa: Gnosis, Philosophy and the Order of Knowlegde. Bloomington: Indiana University Press.

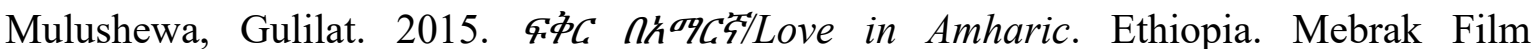
Production.

Naficy, Hamid, and Teshome Gabriel (eds). 1993. Otherness and the Media: The Ethnography of the Imagined and the Imaged. Langhorn: Harwood Academic Publishers. 
Naod, Gashaw. 2011. HGG/Zeraff. Ethiopia: Mekdi Production.

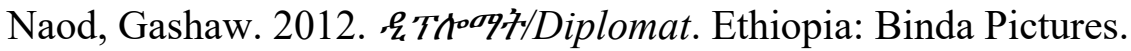

Naod, Gashaw. 2014. Interview conducted by Michael W. Thomas. Addis Ababa, July 1.

Ndlovu-Gatsheni, Sabelo J. 2009. “Africa for Africans or Africa for'natives' only? 'New nationalism' and nativism in Zimbabwe and South Africa”. Africa Spectrum 44(1): 61-78.

Nyamnjoh, Francis B. 2010. "Racism, ethnicity and the media in Africa: Reflections inspired by studies of xenophobia in Cameroon and South Africa". Africa Spectrum 45(1): 5793.

Okoye, Chukwuma. 2010. "Looking back: Nigerian video film anthropologises the West”. African Studies Bulletin 72 (October 2010): 76-90.

Orgad, Shani. 2012. Media Representation and the Global Imagination. Cambridge: Polity.

Osakwe, Chukwuma. 2012. J.U.D.E. Nigeria: Cross Cultural Connect.

Ray, Carina E. 2015. Crossing the Color Line: Race, Sex and the Contested Politics of Colonialism in Ghana. Athens: Ohio University Press.

Rønning, Helge. 2014. "How much 'soft power' does China have in Africa?" Paper presented at the international conference China and Africa Media, Communications and Public Diplomacy, Beijing, September 10-11.

Said, Edward. 1978.Orientalism. New York: Vintage.

Shen, Simon. 2009.“A constructed (un)reality on China's re-entry into Africa: The Chinese online community perception of Africa (2006-2008)".Journal of Modern African Studies 47(3): 425-448. doi: http://dx.doi.org/10.101017/S0022278X09003991.

Silverstone, Roger. 2007. Media and Morality: On the Rise of the Mediapolis. Cambridge: Polity.

Taylor, Charles. 2004. Modern Social Imaginaries. Durham: Duke University Press.

Thakur, Monika. 2009. "Building on progress? Chinese engagement in Ethiopia". South African Institute of International Affairs Occasional Paper 38: 4-23.

Thomas, Michael W. 2015. "The local film sensation in Ethiopia: Aesthetic comparisons with African cinema and alternative experiences". Black Camera: An International Film Journal 7(1): 17-41.

Turton, David (ed). 2006. Ethnic Federalism: The Ethiopian Experience in Comparative Perspective. Oxford: James Currey. 
Xin, Xin. 2009. "Xinhua news agency in Africa". Journal of African Media Studies 1(3): 363-377. doi: http://dx.doi.org/10.1386/jams.1.3.363/1.

Wasserman, Herman (ed.). 2011. Popular Media, Democracy and Development in Africa, New York: Routledge. 